\title{
Rhodosporidium sp. DR37: a novel strain for production of squalene in optimized cultivation conditions
}

\author{
Shahryar Shakeri ${ }^{*} \mathbb{D}$, Farshad Khoshbasirat and Mahmood Maleki
}

\begin{abstract}
Background: Rhodosporidium strain, a well-known oleaginous yeast, has been widely used as a platform for lipid and carotenoid production. However, the production of squalene for application in lipid-based biofuels is not reported in this strain. Here, a new strain of Rhodosporidium sp. was isolated and identified, and its potential was investigated for production of squalene under various cultivation conditions.

Results: In the present study, Rhodosporidium sp. DR37 was isolated from mangrove ecosystem and its potential for squalene production was assessed. When Rhodosporidium sp. DR37 was cultivated on modified YEPD medium (20 g/L glucose, $5 \mathrm{~g} / \mathrm{L}$ peptone, $5 \mathrm{~g} / \mathrm{L} \mathrm{YE}$, seawater $\left.(50 \% \mathrm{v} / \mathrm{v}), \mathrm{pH} 7,30^{\circ} \mathrm{C}\right), 64 \mathrm{mg} / \mathrm{L}$ of squalene was produced. Also, squalene content was obtained as $13.9 \%$ of total lipid. Significantly, use of optimized medium ( $20 \mathrm{~g} / \mathrm{L}$ sucrose, $5 \mathrm{~g} / \mathrm{L}$ peptone, seawater $\left.(20 \% \mathrm{v} / \mathrm{v}), \mathrm{pH} 7,25^{\circ} \mathrm{C}\right)$ allowed highest squalene accumulation $(619 \mathrm{mg} / \mathrm{L})$ and content $(21.6 \%$ of total lipid) in Rhodosporidium sp. DR37. Moreover, kinetic parameters including maximum specific cell growth rate $\left(\mu_{\text {max }} \mathrm{h}^{-1}\right)$, specific lipid accumulation rate $\left(q_{p}, \mathrm{~h}^{-1}\right)$, specific squalene accumulation rate $\left(q_{s q^{\prime}} \mathrm{h}^{-1}\right)$ and specific sucrose consumption rate $\left(q_{s^{\prime}} \mathrm{h}^{-1}\right)$ were determined in optimized medium as $0.092,0.226,0.036$ and 0.010 , respectively.

Conclusions: This study is the first report to employ marine oleaginous Rhodosporidium sp. DR37 for accumulation of squalene in optimized medium. These findings provide the potential of Rhodosporidium sp. DR37 for production of squalene as well as lipid and carotenoids for biofuel applications in large scale.
\end{abstract}

Keywords: Rhodosporidium sp. DR37, Lipid-based biofuels, Squalene production, Optimized medium

\section{Background}

Squalene

$(2,6,10,15,19,23$-hexamethyltetracosa2,6,10,14,18,22-hexaene,), a six double-bonded triterpenic hydrocarbon $\left(\mathrm{C}_{30} \mathrm{H}_{50}\right)$, is widely produced in microorganisms and the other higher organisms such as plants and animals via mevalonate (MVA) or 2-C-methylD-erythritol 4-phosphate (MEP) biosynthetic pathways [1]. Squalene is the main precursor of sterols biosynthesis in plants and animals [2]. It has been shown that

*Correspondence: sh.shakeri@kgut.ac.ir

Department of Biotechnology, Institute of Science and High Technology and Environmental Sciences, Graduate University of Advanced

Technology, Kerman, Iran squalene has antioxidant and anticancer activities with broad applications in food and cosmetics industries [35]. Besides, squalene has been used as vaccine adjuvant in vaccine formulations [6]. Recently, squalene has also been successfully converted to the biofuel and used as a diesel fuel by Mazda Motor Corporation (Fuchu, Japan) in 2011 [7]. Lipid-based biofuels have attracted more attention than petroleum-based fuels, after growing energy demand and global warming concerns [8]. Oleaginous microorganisms are promising sources for production of lipid-based biofuels [9]. For instance, oleaginous yeast strains can accumulate intracellular lipid up to $80 \%$ of their dry cell weight, which can be utilized for production of lipid-based biofuels [10]. Since, the demand for 
squalene has increased during the last decade, microbial production of squalene has been investigated as a promising alternative source for traditional extraction methods from shark liver or plant oils [11]. Microbial strains are capable of producing pollutant-free, low-cost, high-quality and sustainable squalene source as a major interest to lipid-based biofuels industries [12]. For these reasons, screening experiments and metabolic or bioprocess engineering have been used for isolation of naturally squalene producing microorganisms or improvement of squalene production in engineered microbes $[11,13,14]$. Squalene-producing microorganisms have been isolated and identified as yeast, fungi, bacteria, microalga and protists [15]. Recently, a protist (Aurantiochytrium) and a yeast (Pseudozyma) strain have been reported for their potential to produce high amount of squalene $[16,17]$. Aurantiochytrium is known for its potential for production of high amount of polyunsaturated docosahexaenoic acid (DHA) in large scale [18]. Also, co-production of squalene and DHA has been reported by Schizochytrium limacinum SR21 from cheap feedstock of organosolvpretreated spruce hydrolysates [19]. Pseudozyma is a biosurfactant, biodiesel and enzyme-producing yeast [20-22]. In recent years, high squalene producing yeastlike strains of Pseudozyma were isolated and identified, which are potential candidates for commercial production of squalene [16, 23].

This study has focused on oleaginous Rhodosporidium species which is basidiomycete, heterotrophic and fast growing yeast. Rhodosporidium accumulate high amount of intracellular lipid and carotenoids [24]. Till now, intensive researches have been done on production of lipid and carotenoids in this strain [25-28]. A wide range of carbon and nitrogen substrates utilization, fast growing and high content of lipid (30-70\% of dry cell weight) and carotenoids such as $\beta$-carotene make Rhodosporidium useful for large-scale production of valuable metabolites [29]. Recently, R. toruloides DEBB 5533 has been used for pilot-scale oil production using sugarcane juice. Oil was produced with high productivity using fed-batch cultivation in bioreactor with working volume of $1000 \mathrm{~L}$ and then successfully converted to biodiesel with high performance in engine tests [30]. Also, genetic engineering of Rhodosporidium species for production of novel chemicals [31], in addition to co-production of carotenoids and lipid from cheap feedstocks [32], indicates that this strain is a promising candidate for production of high-value bioproducts. However, this biotechnologically important yeast strain is not being considered as a possible candidate for squalene production. Broad range substrate utilization and significant tolerance to biomass-derived inhibitors [33] make Rhodosporidium a promising candidate for economically feasible co-production of squalene with lipids, carotenoids and enzymes. Since, in carotenoid-producing yeasts, MVA pathway for production of carotenoids and squalene is the same, this possibility may exist to find some Rhodosporidium species with potential for production of squalene as much as carotenoids or lipids [24]. To the best of our knowledge, this study is the first effort using Rhodosporidium species for production of squalene. In this study, a newly isolated Rhodosporidium species was assessed for its potential for production of squalene. Furthermore, one factor at a time method was used for investigation of the individual effects of various factors (carbon and nitrogen sources, seawater concentration, $\mathrm{pH}$ and temperature) on cell growth, lipid and squalene production.

\section{Methods}

\section{Materials and samples collection}

All carbon and nitrogen sources were obtained from Merck (Darmstadt, Germany). Standard squalene was obtained from Sigma (St. Louis, Mo., U.S.A.). All other chemicals and solvents were provided in analytical grade. Seawater samples, fallen leaves of mangrove trees (Avicennia marina and Rhizophora mucronata) and sediments were collected from coastal waters and mangrove forest of Persian Gulf and Oman Sea in south of Iran $\left(26^{\circ} 50^{\prime} 36.0^{\prime \prime} \mathrm{N} 55^{\circ} 41^{\prime} 13.2^{\prime \prime} \mathrm{E}\right.$ and $26^{\circ} 19^{\prime} 30.9^{\prime \prime} \mathrm{N}$ $\left.57^{\circ} 07^{\prime} 28.0^{\prime \prime} \mathrm{E}\right)$. Samples were kept in sterile bags at $4{ }^{\circ} \mathrm{C}$ and sent to the laboratory before use. Also, natural seawater sample with chemical composition including $7810 \mathrm{mg} / \mathrm{L} \mathrm{Na}^{+}, 22,961 \mathrm{mg} / \mathrm{L} \mathrm{Cl}^{-}, 410 \mathrm{mg} / \mathrm{L} \mathrm{Ca}^{2+}$, $1386 \mathrm{mg} / \mathrm{L} \mathrm{Mg}^{2+}, 259 \mathrm{mg} / \mathrm{L} \mathrm{K}^{+}$and $2479 \mathrm{mg} / \mathrm{L} \mathrm{SO}_{4}{ }^{2-}$ was used for preparation of culture media.

\section{Yeast strains isolation}

Samples were plated on medium containing $10 \mathrm{~g} / \mathrm{L}$ glucose, $1 \mathrm{~g} / \mathrm{L}$ peptone, $0.1 \mathrm{~g} / \mathrm{L}$ yeast extract (YE), natural seawater $(50 \% \mathrm{v} / \mathrm{v}), 15 \mathrm{~g} / \mathrm{L}$ agar and supplemented with $300 \mathrm{mg} / \mathrm{L}$ streptomycin and penicillin G. The plates were incubated at $30^{\circ} \mathrm{C}$ for $3-6$ days with regular observation for yeast growth. The obtained single yeast colonies were picked-up and sub-cultured on fresh yeast extract-peptone-dextrose medium (YEPD) (20 g/L glucose, $20 \mathrm{~g} / \mathrm{L}$ peptone, $10 \mathrm{~g} / \mathrm{L}$ YE, $15 \mathrm{~g} / \mathrm{L}$ agar, seawater $(50 \% \mathrm{v} / \mathrm{v})$ and $\mathrm{pH}$ 6.5) and incubated at $30{ }^{\circ} \mathrm{C}$ for $48 \mathrm{~h}$ to obtain pure cultures [34].

\section{Light microscopy and morphological characteristics}

Yeast strains were grown in YEPD broth medium and incubated at $30{ }^{\circ} \mathrm{C}$ for $48 \mathrm{~h}$. Then, morphological characteristics of the isolated yeast strains were determined under light microscope (Zeiss, Germany). 


\section{Molecular and phylogenetic analysis}

An overnight culture of yeast strain was prepared and used for genomic extraction. Universal primers ITS1 (5'-TCCGTAGGTGAACCTGCG-3') and ITS4 (5' -TCC TCCGCTTATTGATATGC-3') were used for amplification of the internal transcribed spacer (ITS). Polymerase chain reaction (PCR) was performed by gradient thermal cycler (Eppendorf, Westbury, NY, USA). The program was set as denaturation for $4 \mathrm{~min}$ at $94{ }^{\circ} \mathrm{C}, 30$ cycles of $30 \mathrm{~s}$ at $94{ }^{\circ} \mathrm{C}, 1 \mathrm{~min}$ at $55^{\circ} \mathrm{C}$ and $90 \mathrm{~s}$ at $72{ }^{\circ} \mathrm{C}$. Final extension was $7 \mathrm{~min}$ at $72{ }^{\circ} \mathrm{C}$ [35]. PCR amplicons were purified and sequenced by Bioneer. Resulting sequences were edited by BioEdit program (BioEdit 7.2) and were searched using Basic Local Alignment Search Tool (BLAST) (http://blast.ncbi.nlm.nih.gov). ClustalX program was used for sequence alignment and then generation of phylogenetic tree was done using neighbor-joining method and MEGA4 software [36]. The tree reliability was evaluated by bootstrap analysis of 1000 replicates.

\section{Strain selection and cultivation}

Strain DR37 was isolated based on its characteristic for squalene production. This strain was cultivated in modified YEPD broth medium (20 g/L glucose, $5 \mathrm{~g} / \mathrm{L}$ peptone, $5 \mathrm{~g} / \mathrm{L} \mathrm{YE}$, seawater $(50 \% \mathrm{v} / \mathrm{v})$ and $\mathrm{pH} 7)$ and incubated at $30{ }^{\circ} \mathrm{C}$ and $150 \mathrm{rpm}$.

\section{Optimization of culture conditions}

For investigation the individual effect of various chemical and physical parameters on cell growth, lipid and squalene production by Rhodosporidium sp. DR37, six sets of one factor at a time experiments were designed and previous optimum results were used for subsequent experiments. The first step to start the one factor at a time experiments was to find the optimum sole carbon source. Five carbon sources $(20 \mathrm{~g} / \mathrm{L})$ (glucose, sucrose, glycerol, starch and olive oil) were tested for their effect on cell growth, lipid and squalene production. The next step was investigation of the effect of five nitrogen sources $(5 \mathrm{~g} / \mathrm{L})$ (YE, malt extract (ME), peptone, ammonium chloride and sodium nitrate) with sucrose as the best sole carbon source. Seawater concentration $(50 \% \mathrm{v} / \mathrm{v})$ was constant in all above experiments. During carbon source experiments, YE and peptone (5 g/L each) were used as nitrogen source. Also, $20 \mathrm{~g} / \mathrm{L}$ sucrose was used as the carbon source during nitrogen source experiments. Afterward, the effect of different concentrations of seawater $(0,20$, 50,70 and $100 \% \mathrm{v} / \mathrm{v}$ ) was assessed along with $20 \mathrm{~g} / \mathrm{L}$ sucrose and $5 \mathrm{~g} / \mathrm{L}$ peptone as selected carbon and nitrogen sources, respectively. Also, different concentrations of selected carbon source (sucrose, g/L) $(10,20,40,60$,
80 and 100) were investigated for their effect on cell growth, lipid and squalene production. Accordingly, the effects of various growth parameters, including temperature $\left(15,20,25,30\right.$ and $\left.37^{\circ} \mathrm{C}\right)$ and initial medium $\mathrm{pH}$ (5.0, 7.0 and 9.0) were investigated in medium containing $20 \mathrm{~g} / \mathrm{L}$ sucrose, $5 \mathrm{~g} / \mathrm{L}$ peptone and seawater $(20 \% \mathrm{v} / \mathrm{v})$. Initial $\mathrm{pH}$ of the medium was adjusted to 5.0, 7.0 and 9.0 by using hydrochloric acid and sodium hydroxide solutions. Rhodosporidium sp. DR37 was cultured in 250-mL Erlenmeyer flasks containing $50 \mathrm{~mL}$ broth fermentation medium. The experiments were carried out in triplicate and incubated for 3 days at $150 \mathrm{rpm}[16,26]$.

\section{Determination of cell growth and biomass}

The growth of yeast cells were determined by measuring optical density (OD) of harvested cells at phosphate buffered saline (PBS) and $600 \mathrm{~nm}$. Cell biomass, expressed as cell dry weight $(\mathrm{CDW})$ was harvested by centrifugation (1300 g for $5 \mathrm{~min}$ ) and pellets were dried at $105{ }^{\circ} \mathrm{C}$ for $18 \mathrm{~h}$ to constant weight and the weight was determined gravimetrically [18].

\section{Lipid extraction and TLC analysis}

A certain amount of freeze-dried cells was suspended in $2 \mathrm{~mL}$ distilled water in screw cap test tubes. The cells were disrupted by ultrasonication (Hielscher UP200S, Germany; amplitude $60 \%$ and 0.5 cycle for $5 \mathrm{~min}$ ) and then $2.5 \mathrm{~mL}$ chloroform and $5 \mathrm{~mL}$ methanol were added. Cell suspension was sonicated again and homogenized with T10 basic IKA homogenizer. $2.5 \mathrm{~mL}$ chloroform and $2.5 \mathrm{~mL}$ distilled water were added and vortexed for $30 \mathrm{~s}$. Resulting suspension was centrifuged at $1300 \mathrm{~g}$ for $15 \mathrm{~min}$ to separate two phases. The organic bottom layer was transferred to a pre-weighed tube and the solvent was evaporated. The amount of lipid was determined gravimetrically [37]. Thin layer chromatography (TLC) silica gel plates coated with fluorescent indicator $\mathrm{F}_{254}$ were used for analysis of extracted lipids. Hydrocarbons such as squalene were separated with developing solvent of hexane/chloroform (9:1). Afterward, the TLC plates were exposed to $\mathrm{H}_{2} \mathrm{SO}_{4}(20 \%)$ and then visualized by heating at $70{ }^{\circ} \mathrm{C}$ for $60 \mathrm{~min}$ [38].

\section{Fatty acid methyl esters analysis}

Total lipid was converted into fatty acid methyl esters (FAMEs) by methanolic sulfuric acid $(4 \% \mathrm{v} / \mathrm{v})$ at $80^{\circ} \mathrm{C}$ for $90 \mathrm{~min}$ in sealed vials. Then $1 \mathrm{~mL}$ of $\mathrm{H}_{2} \mathrm{O}$ was added and FAMEs were extracted by hexane extraction $(3 \times 2 \mathrm{~mL})$. FAMEs were dried over anhydrous $\mathrm{Na}_{2} \mathrm{SO}_{4}$ and solvent was removed by evaporation. The samples were stored at $4{ }^{\circ} \mathrm{C}$ prior analysis. Gas chromatography (GC) analysis was performed using Agilent 6890 equipped with a flame-ionization detector (FID) and DB-23 
(30 m $\times 0.32 \mathrm{~mm}, 0.25 \mu \mathrm{m}$; Agilent Technologies, USA) capillary column. $0.5 \mu \mathrm{L}$ of FAMEs sample was injected under splitless injection mode. Nitrogen was used as carrier gas and temperature of injector and detector was set at $300{ }^{\circ} \mathrm{C}$. Column temperature program were $50{ }^{\circ} \mathrm{C}$; $2 \mathrm{~min}, 10{ }^{\circ} \mathrm{C} / \mathrm{min}$ to $180{ }^{\circ} \mathrm{C} ; 5 \mathrm{~min}, 5{ }^{\circ} \mathrm{C} / \mathrm{min}$ to $240{ }^{\circ} \mathrm{C}$; 7 min. C19:0-FAME (Sigma, USA) was used as an internal standard [39].

\section{Quantitative determination of squalene by HPLC analysis}

Squalene was identified and quantified by high-performance liquid chromatography (HPLC) (Agilent, 1100 Series, USA) equipped with a Zorbax, sb-C18 $(4.6 \times 250 \mathrm{~mm}, 5$ micron $)$ column. Lipids were saponified using $0.5 \mathrm{M}$ potassium hydroxide containing ethanol $(0.5 \mathrm{M} \mathrm{KOH} / \mathrm{EtOH})$ at $90{ }^{\circ} \mathrm{C}$ for $1 \mathrm{~h}$. Then non-saponifiable lipids were extracted with hexane. Afterward, solvent was evaporated and squalene redissolved with $1 \mathrm{~mL}$ of acetonitrile/tetrahydrofuran (THF) (9:1, v/v) [13]. Acetonitrile/THF (80:20, v/v) was considered as mobile phase at a flow rate of $1 \mathrm{~mL} / \mathrm{min}$ and ran under isocratic conditions. The sample injection volume was $10 \mu \mathrm{L}$ and the column temperature was set at $30{ }^{\circ} \mathrm{C}$ and identification and quantification were done at $210 \mathrm{~nm}$. Squalene (St. Louis, Mo., U.S.A.) was used as external standard for squalene quantification. A standard calibration curve was established by plotting peak area against concentration, by using different concentrations of squalene [40].

\section{Fourier-transform infrared spectroscopy (FT-IR) analysis}

IR spectrum of purified squalene was determined between 4000 and $400 \mathrm{~cm}^{-1}$ using a Bruker ALPHA FT-IR spectrometer. Three spectral replicates were determined for purified squalene sample.

\section{Kinetic parameters calculation}

The maximum specific cell growth rate $\left(\mu_{\max }, \mathrm{h}^{-1}\right)$, specific lipid accumulation rate $\left(q_{p}, \mathrm{~h}^{-1}\right)$, specific squalene accumulation rate $\left(q_{s q}, \mathrm{~h}^{-1}\right)$ and specific sucrose consumption rate $\left(q_{s}, \mathrm{~h}^{-1}\right)$ were determined according to Ji et al. [41]. The growth yield $\left(Y_{x / s}, \%\right)$, lipid yield $\left(Y_{p / s}\right.$, $\%)$, and squalene yield $\left(Y_{s q / s}, \%\right)$ were calculated according to Ren et al. [42], where $\mathrm{x}, \mathrm{p}$, sq and s are the amount $(\mathrm{g} / \mathrm{L})$ of biomass, lipid, squalene and residual sucrose, respectively.

\section{Statistical analysis}

Analysis of variance (ANOVA) was used for data analysis with GraphPad Prism 8.0.1 ( $P<0.05$ was used for significant difference among means). The results are presented as the mean \pm standard deviation of three replicates.

\section{Results and discussion}

Isolation and identification of Rhodosporidium sp. DR37

In this study, a novel strain of Rhodosporidium was isolated and identified which is able to produce and accumulate large amount of intracellular lipid granules rich in squalene. Strain DR37 was isolated from water samples obtained from mangrove ecosystem of Qeshm, Iran. Morphology of DR37 colonies was observed as smooth, red, convex and round on the YEPD agar medium (Fig. 1a). Light microscopy showed single cells of DR37 containing red pigment and possess size ranging from 2 to $8 \mu \mathrm{m}$ (Fig. 1b, arrow). Two phases of yeast-like and dikaryotic filamentous were observed after 20 days of incubation at $30{ }^{\circ} \mathrm{C}$ (Fig. 1c, arrow). As shown, arrow indicated an elongated basidium formed from germination of teliospore. Haploid basidiospores will emerge, germinate and form yeast phase of Rhodosporidium species [43]. The teleomorphic reproduction involves a transition between yeast phase and dikaryotic filamentous phase. These two phases are common features of Rhodosporidium species in sexual reproduction cycle [44].

\section{Phylogenetic analysis of strain DR37}

Phylogenetic tree of strain DR37 was generated by Mega $\times$ based on ITS1, 5.8S rRNA and ITS2 regions. Phylogenetic analysis confirmed Rhodotorula and Rhodosporidium species were the closest relatives of strain DR37 and indicated strain DR37 belongs to the genus

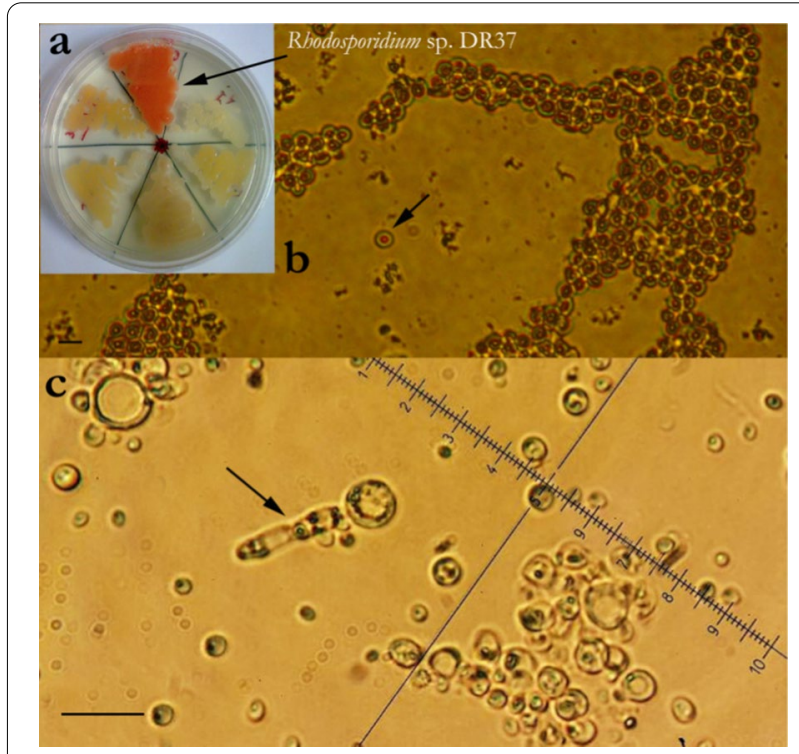

Fig. 1 Morphological characteristics of strain DR37 (scale bar $10 \mu \mathrm{m})$. a Red colonies of strain DR37. $\mathbf{b}$ Yeast phase and a single cell containing red pigment (arrow), carotenoids are well shown as intracellular red pigments in yeast phase. c Elongated basidium (arrow) formed from germination of teliospore 
of Rhodotorula (Fig. 2). These results were in agreement with data obtained after major revision on subphylum Pucciniomycotina published by Wang et al. [45]. It is shown that Rhodosporidium species is categorized under the revised Rhodotorula genus [46]. Phylogenetic analysis showed nucleotide sequences of ITS1, 5.8S rRNA and ITS2 from DR37 had 98\% similarity to the species of Rhodosporidium JN383899. However, the main difference between Rhodosporidium and Rhodotorula species is the presence or absence of sexual reproduction, respectively. As a result, formation of basidium was observed by strain DR37 which is a part of sexual reproduction of Rhodosporidium species. Subsequently, based on morphological and phylogenetic characteristics, strain DR37 was named Rhodosporidium sp. DR37 with GenBank accession number MG022778.

\section{Determination of fatty acid profile of Rhodosporidium sp.}

\section{DR37}

Rhodosporidium sp. DR37 was cultivated in modified YEPD broth medium for $72 \mathrm{~h}$. Lipid was extracted and subsequently esterified and analyzed by GC.
Rhodosporidium sp. DR37 produced $5.2 \mathrm{~g} / \mathrm{L} \mathrm{CDW}$ and $0.46 \mathrm{~g} / \mathrm{L}$ lipid. GC results showed that profile of fatty acids produced by Rhodosporidium sp. DR37 was similar to the other strain of Rhodosporidium TJUWZ4 [26]. The major fatty acids (\% of TFA) were identified as C14:0 (myristic acid, 1.84\%), C16:0 (palmitic acid, 26.22\%), C16:1 (palmitoleic acid, 1.87\%), C18:0 (stearic acid, 6.49\%), C18:1 (oleic acid, 47.16\%) and C18:2 (linoleic acid, 12.91\%) (Table 1).

Table 1 Fatty acid profile of Rhodosporidium sp. DR37

\begin{tabular}{lc}
\hline Fatty acids & (\% of TFA) \\
\hline C14:0 & 1.84 \\
C16:0 & 26.22 \\
C16:1 & 1.87 \\
C18:0 & 6.49 \\
C18:1 & 47.16 \\
C18:2 & 12.91 \\
Others & 3.51 \\
Total & 100 \\
\hline
\end{tabular}

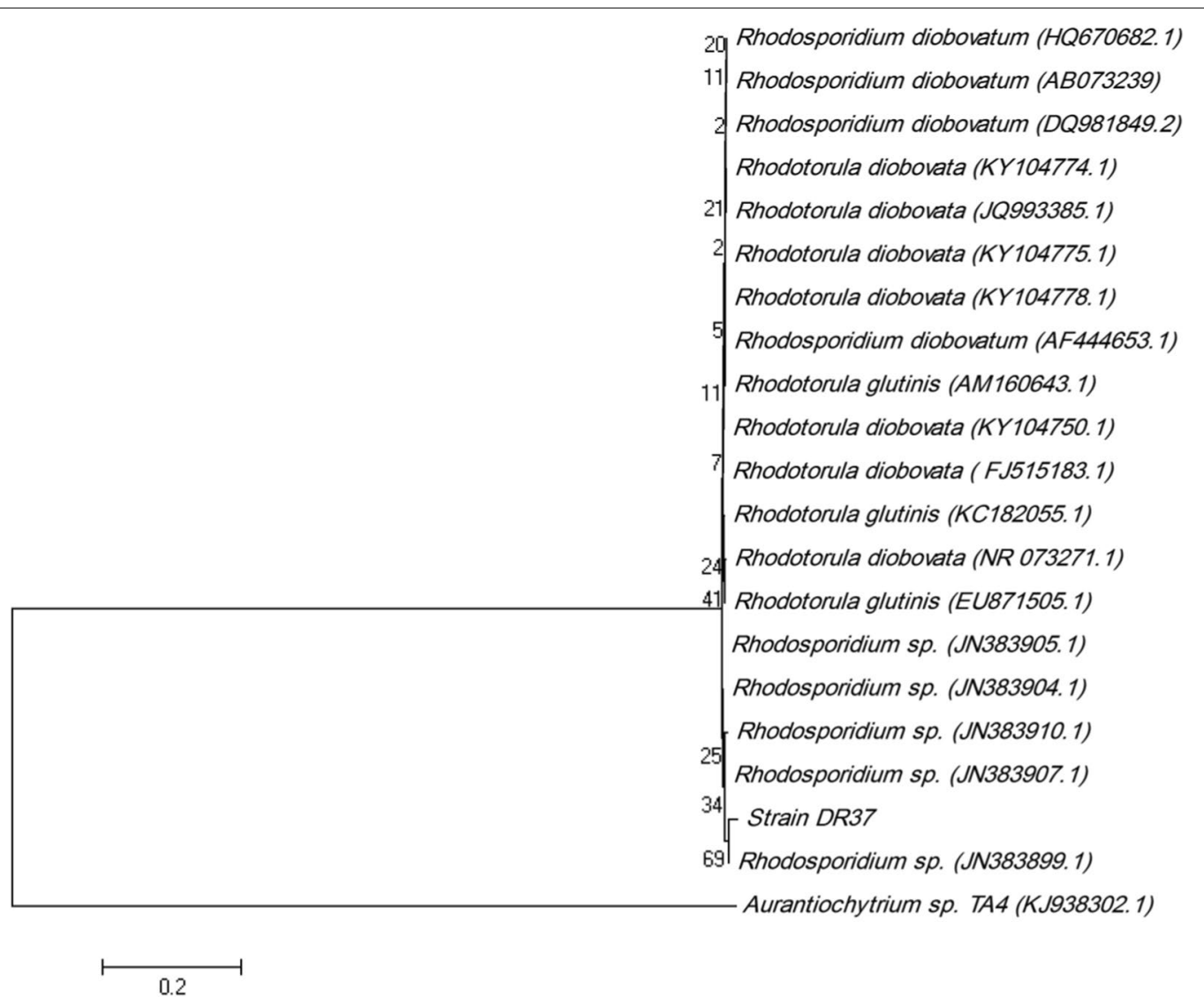

Fig. 2 The phylogenetic tree of Rhodosporidium sp. DR37. Nucleotide sequences of ITS1, 5.8S rRNA, ITS2 were sequenced and tree was generated by neighbor-joining methods with bootstrap values (> 50\%) from 1000 replicates. Aurantiochytrium sp. TA4 was considered as out-group 
Total content of saturated and unsaturated fatty acids was $34.55 \%$ and $61.94 \%$ of TFA, respectively. Oleic acid, palmitic acid and linoleic acid were predominant fatty acids with $86.29 \%$ of TFA. Higher content of these fatty acids among other fatty acids makes Rhodosporidium oil as a good feedstock for production of biodiesel with desirable properties [47]. The obtained profile of fatty acids from Rhodosporidium showed a similar composition to fatty acids obtained from plant oils and can be considered as a microbial alternative for production of biodiesel [48, 49]. Similar to Rhodosporidium sp. DR37, oleic acid was produced with high content among other fatty acids in total lipid (53.34\%) by Rhodosporidium toruloides 21167 in a medium containing cassava starch hydrolysate at shake flask. It is notable that long-chain fatty acids containing of 16 and 18 carbon atoms are very desirable for biodiesel production [50].

\section{TLC analysis of total lipids}

Figure 3a shows TLC of total lipid extracted from biomass of Rhodosporidium sp. DR37. Total lipids were extracted from Rhodosporidium and subjected to TLC and then, squalene and triacylglycerol (TAG) were separated by developing solvent. After visualization step, squalene spot was identified based on standard squalene. The RF value of visualized squalene spot from Rhodosporidium sp. DR37 was same as the standard squalene. TLC screening of squalene production among microbial strains is a simple and fast method in comparison to chromatography methods such as GC and HPLC [13]. As shown in Fig. 3a, TAG and steryl esters (SE) are recognized together with squalene which is in accordance with results of Milla et al. [51]. In another study, Patel et al. analyzed total lipid extract from Aurantiochytrium sp. T66 (ATCC PRA-276) by TLC. The two spots of SE
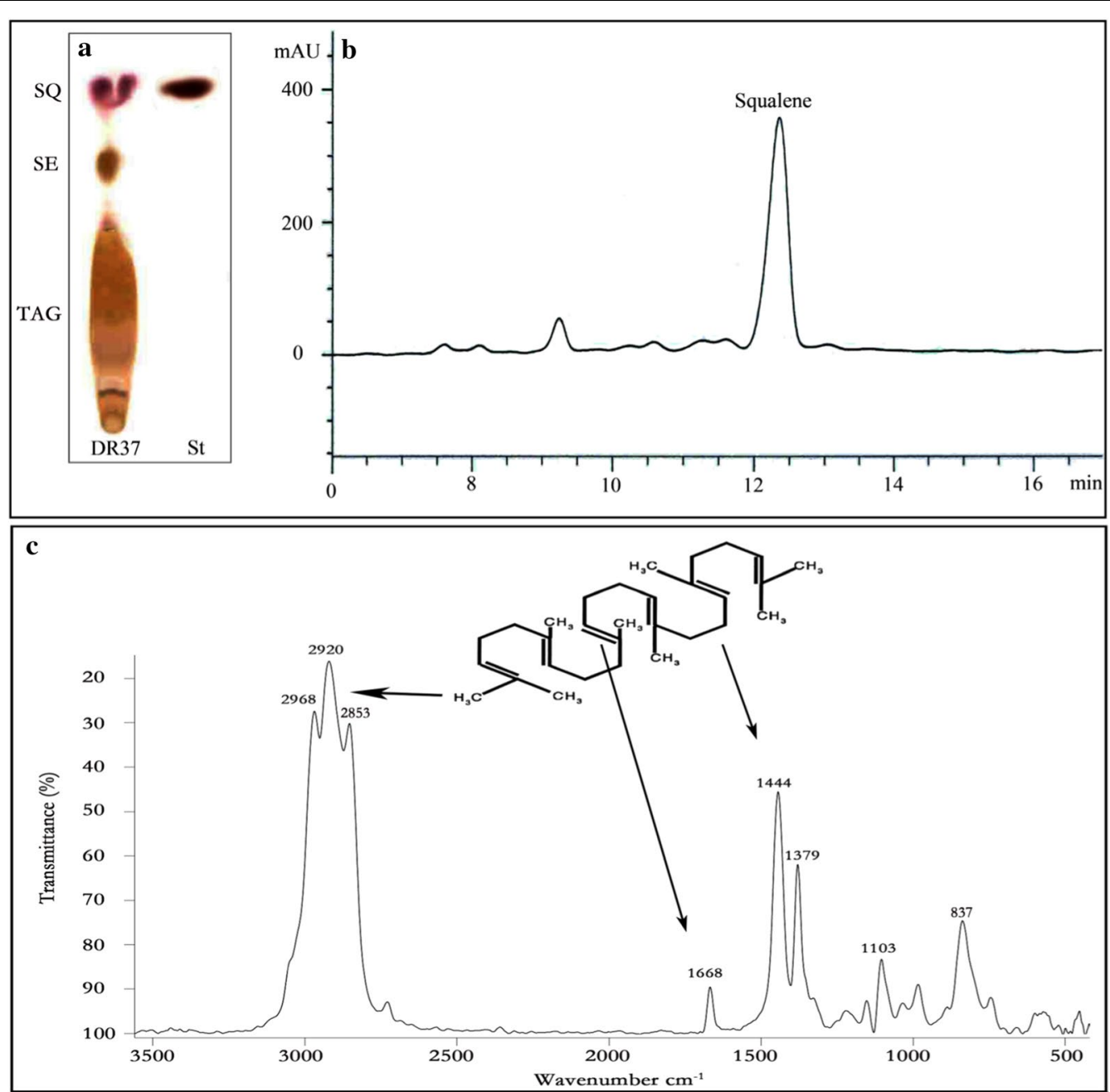

Fig. 3 a TLC analysis of total lipid extracted from biomass of Rhodosporidium sp. DR37. Standard squalene was used as control for identification of squalene in the samples. b HPLC chromatogram of non-saponifiable lipid extract (squalene) from Rhodosporidium sp. DR37 oil. c The infrared (IR) spectrum of purified squalene. SQ squalene, TAG triacylglycerol, SE steryl esters 
and TAG were detected and recognized together with the squalene spot [52].

\section{Quantitative determination of squalene by HPLC}

Further purification of squalene was performed by saponification of total lipid and then squalene extraction was carried out by $n$-hexane from non-saponifiable fraction. Detection and quantitative evaluation of purified squalene was performed by HPLC. Chromatographic peak of squalene was identified based on the retention time of standard squalene. As shown in Fig. 3b, the elution time for extracted squalene was $12.37 \mathrm{~min}$. Then, squalene concentration was determined based on peak area and using a calibration curve. Squalene was produced at concentration of $64 \mathrm{mg} / \mathrm{L}$ and content of $13.9 \%$ of total lipid after $72 \mathrm{~h}$ of Rhodosporidium sp. DR37 cultivation in modified YEPD medium. Rhodosporidium strains are well known for their potential for production of carotenoids and lipids in their CDW. However, squalene content has been reported to be very low in Rhodosporidium strains in comparison to genetically modified yeasts or naturally squalene producing microorganisms such as Schizochytrium, Aurantiochytrium and Pseudozyma. A genetically modified Saccharomyces cerevisiae (strain YUG37-ERG1) was reported to accumulate $18.0 \mathrm{mg} / \mathrm{L}$ squalene [53] which is much lower than naturally produced squalene $(64 \mathrm{mg} / \mathrm{L})$ by Rhodosporidium sp. DR37. Kaya et al. reported an Aurantiochytrium strain which accumulates high amount of squalene with concentration of $1.29 \mathrm{~g} / \mathrm{L}$ after 4 days of cultivation [38]. Also, another extended screening program was performed for isolation of squalene producing thraustochytrid strains in Okinawa mangrove forest. 14 novel squalene producing thraustochytrid strains were isolated and identified. The amount of produced squalene was determined between 7.54 and $13.9 \mathrm{~g} / \mathrm{g}$ CDW [54].

\section{FT-IR analysis of squalene}

The IR spectrum of squalene is shown in Fig. 3c. Three intense bands corresponding to $\mathrm{C}-\mathrm{H}$ stretching were observed at 2968, 2920 and $2853 \mathrm{~cm}^{-1}$. Furthermore, four intense skeletal vibration modes were observed at 1444, 1379, 1103 and $837 \mathrm{~cm}^{-1}$. More importantly, one low-intensity band corresponding to $\mathrm{C}=\mathrm{C}$ stretching was observed at $1668 \mathrm{~cm}^{-1}$. These IR results are completely in agreement with Hall et al. [55]. They found an analytically important band at $1666 \mathrm{~cm}^{-1}$ and $1670 \mathrm{~cm}^{-1}$ in FT-IR and Raman analysis of squalene, respectively. These bands corresponding to symmetric stretching of six double bonds in squalene structure can be used to discriminate squalene from TAG or diacylglycerol (DAG) in FT-IR or Raman analysis.

\section{The effect of carbon sources on cell growth, lipid} and squalene production

Optimum condition for squalene production was investigated by one factor at the time method. The cell growth, lipid and squalene production were assessed on various carbon and nitrogen sources and seawater concentrations under various temperatures and $\mathrm{pH}$. Glucose, sucrose, glycerol, olive oil and starch were used to investigate their effect on cell growth, lipid and squalene production in shake flask. As shown in Fig. 4, Rhodosporidium sp. DR37 was able to grow on all carbon sources. The maximum CDW was obtained in medium with glucose as sole carbon source $(5.2 \mathrm{~g} / \mathrm{L})$. Rhodosporidium $\mathrm{sp}$. DR37 produced lipid in almost all carbon sources except in medium containing starch. This result was in agreement with previous data obtained for Rhodosporidium TJUWZ4 by Wang et al. [26]. Their results showed that Rhodosporidium TJUWZ4 produced very low lipid content $(0.039 \mathrm{~g} / \mathrm{L})$ in medium containing starch as sole carbon source. No statistically significant difference was observed between CDW or squalene values obtained from medium containing sucrose or olive oil as sole carbon source $(p<0.05)$. Maximum lipid concentration of $1.2 \mathrm{~g} / \mathrm{L}$ was achieved in medium containing olive oil as carbon source. However, sucrose was selected to be the best carbon source for squalene production. The squalene concentration was slightly higher in Rhodosporidium grown on sucrose $(204 \mathrm{mg} / \mathrm{L})$ in comparison to olive oil $(194 \mathrm{mg} / \mathrm{L})(p>$ $0.05)$. Therefore, sucrose was selected as the best carbon source for further optimization experiments. Sucrose is one of the main compositions of sugarcane molasses as a low-cost carbon source for production of high-added value bioproducts by microorganisms [56]. Rhodosporidium species is also capable of accumulating high amount

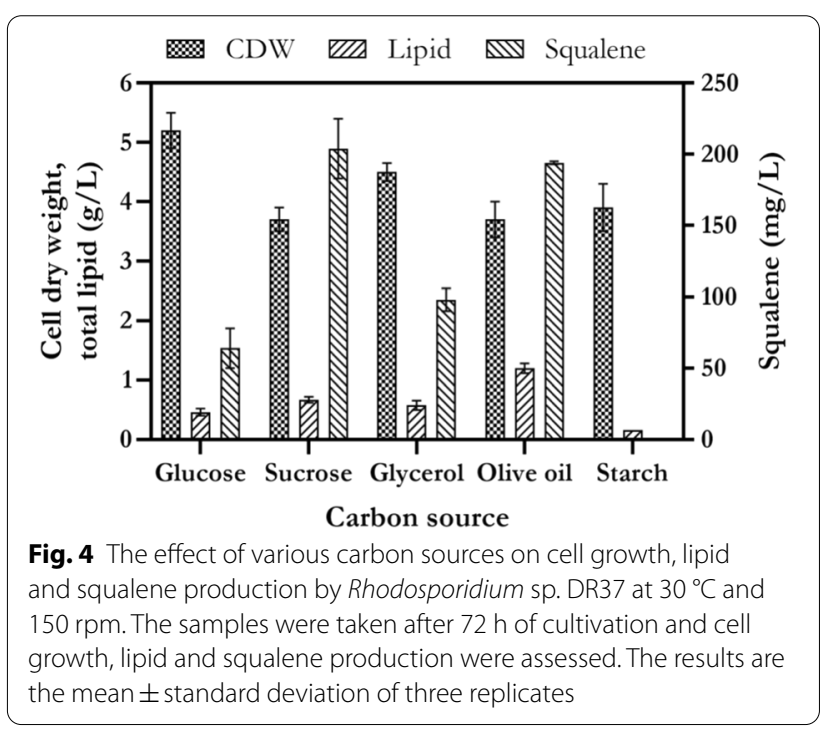


of lipid from 5 carbon carbohydrates such as xylose, which is presented in plant biomass hydrolysates [57].

\section{The effect of nitrogen sources on cell growth, lipid and squalene production}

Five different nitrogen sources including organic (YE, peptone and $\mathrm{ME}$ ) and inorganic (ammonium chloride, and sodium nitrate) were used to investigate their effect on biomass, lipid and squalene production. As shown in Fig. 5, results indicated YE, peptone and ME supported considerable cell growth in comparison to inorganic nitrogen sources. A significant difference was observed between $p$ values obtained from organic and inorganic nitrogen sources $(p<0.05)$. Lipid concentration was 0.55 , 1.11 and $0.69 \mathrm{~g} / \mathrm{L}$, when $\mathrm{YE}$, peptone and ME were used as sole nitrogen source in culture medium, respectively. Among nitrogen sources, YE and peptone were found to have a statistically significant effect on squalene production $(p<0.05)$. The highest squalene concentration $(386 \mathrm{mg} / \mathrm{L})$ was obtained in culture medium containing peptone as sole nitrogen source. Squalene concentration was 199 and $110 \mathrm{mg} / \mathrm{L}$, when $\mathrm{YE}$ and ME were used as sole nitrogen source in culture medium, respectively. Maximum amounts of lipid and squalene were obtained in culture medium with peptone as sole nitrogen source. These results showed that organic nitrogen sources such as peptone are effective in production of squalene by marine strain Rhodosporidium sp. DR37. Nitrogen sources are necessary for cell growth and maintenance of Rhodosporidium during exponential growth phase in the initial fermentation stage with balanced $\mathrm{C} / \mathrm{N}$ ratio [29]. Peptones are derived by enzymatic digestion or acid hydrolysis of animal and plant tissues and

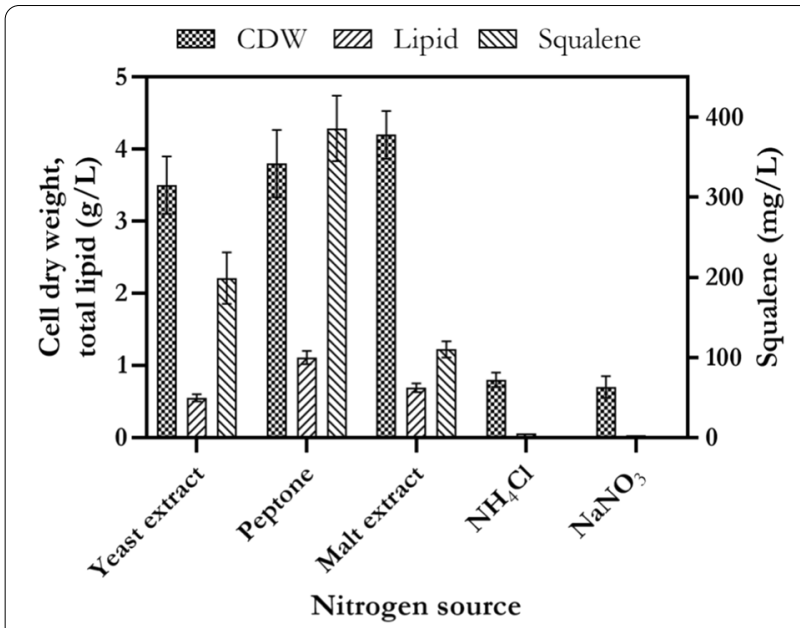

Fig. 5 The effect of various nitrogen sources on cell growth, lipid and squalene production by Rhodosporidium sp. DR37 at $30^{\circ} \mathrm{C}$ and $150 \mathrm{rpm}$ usually used for enrichment of culture medium to promote cell growth and multiplication [58]. As shown in Fig. 5, organic nitrogen sources such as peptone and YE supported better cell growth, lipid and squalene production in comparison to inorganic nitrogen sources. The reason for this can be explained by composition of peptone or YE. Peptone and YE have a rich composition of amino acids, vitamins, organic and inorganic minerals to support cell growth and product formation [59]. On the other hand, inorganic nitrogen sources such as $\mathrm{NH}_{4} \mathrm{Cl}$ or $\mathrm{NaNO}_{3}$ may change some chemical parameters such as $\mathrm{pH}$ in broth medium and subsequently, cause negative effects on cell growth and product formation [60]. As mentioned above, maximum levels of CDW, lipid and squalene were produced by Rhodosporidium sp. DR37, when peptone was used as sole nitrogen source in culture medium. Besides, lipid accumulation in Rhodosporidium could be achieved by a proper carbon-to-phosphorus $(\mathrm{C} / \mathrm{P})$ ratio, regardless of high amount of nitrogen source in fermentation medium [61].

\section{The effect of salinity on cell growth, lipid and squalene production}

The effect of different concentrations of seawater $(0,20$, 50,70 and $100 \% \mathrm{v} / \mathrm{v}$ ) was assessed on cell growth, lipid and squalene production by Rhodosporidium sp. DR37, in culture medium containing $20 \mathrm{~g} / \mathrm{L}$ sucrose and $5 \mathrm{~g} / \mathrm{L}$ peptone as selected carbon and nitrogen sources, respectively. As shown in Fig. 6, Rhodosporidium sp. DR37 was capable of growing and producing biomass between $1.6-3.9 \mathrm{~g} / \mathrm{L}$ in medium containing $0-100 \%$ seawater concentration. Addition of $20 \% \mathrm{v} / \mathrm{v}$ seawater to the culture medium, resulted in production of lipid at its maximum level $(1.86 \mathrm{~g} / \mathrm{L})$ in comparison to other media. Lowest amount of lipid production was observed in medium

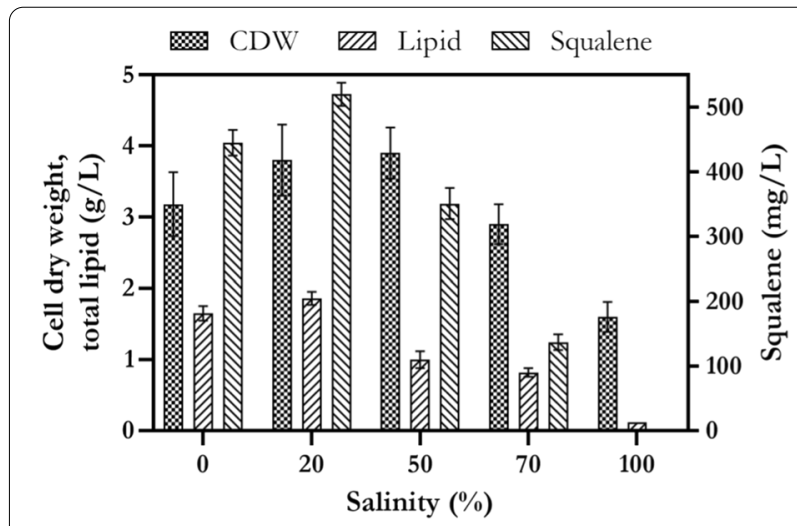

Fig. 6 The effect of different seawater concentrations on cell growth, lipid and squalene production by Rhodosporidium sp. DR37 at $30^{\circ} \mathrm{C}$ and $150 \mathrm{rpm}$ 
with $100 \%$ seawater strength. In fact increasing of seawater concentration showed a statistically significant negative effect $(p<0.05)$ on lipid production by Rhodosporidium sp. DR37. The maximum level of squalene $(520 \mathrm{mg} / \mathrm{L})$ was obtained in medium with $20 \% \mathrm{v} / \mathrm{v}$ seawater and then the amount of squalene was significantly decreased to its minimum level in medium with $70 \% \mathrm{v} / \mathrm{v}$ seawater $(p<0.05)$. Neither lipid nor squalene, produced in $100 \%$ seawater concentration. The results of Tchakouteu et al. [62] research work showed that Rhodosporidium toruloides DSM 4444 was able to tolerate salinity and grow well in medium containing $6 \% \mathrm{w} / \mathrm{v} \mathrm{NaCl}$. The presence of high level salt in culture medium was reported as a good factor for prevention of microbial contaminations in fermentation broth. Interestingly, their results showed that lipid accumulation was stimulated in medium with $4 \% \mathrm{w} / \mathrm{v} \mathrm{NaCl}$. In our study, Rhodosporidium sp. DR37 was able to grow in medium containing $100 \% \mathrm{v} / \mathrm{v}$ seawater. However, the maximum levels of lipid and squalene were obtained in medium containing $20 \% \mathrm{v} / \mathrm{v}$ seawater.

\section{The effect of different concentrations of sucrose on cell growth, lipid and squalene production}

As mentioned before, glucose was a good substrate for production of high amount of biomass, not for squalene accumulation. Therefore, sucrose was selected as proper carbon source for production of higher amount of squalene. So, the effect of various concentrations of sucrose as selected carbon source was investigated on cell growth, lipid and squalene production. As shown in Fig. 7, increase in concentration of sucrose from 10 to $100 \mathrm{~g} / \mathrm{L}$ significantly dropped production of biomass, lipid and squalene. A sharp decrease in the lipid and squalene production was observed in medium with $60 \mathrm{~g} / \mathrm{L}$ sucrose. These results showed that growth and

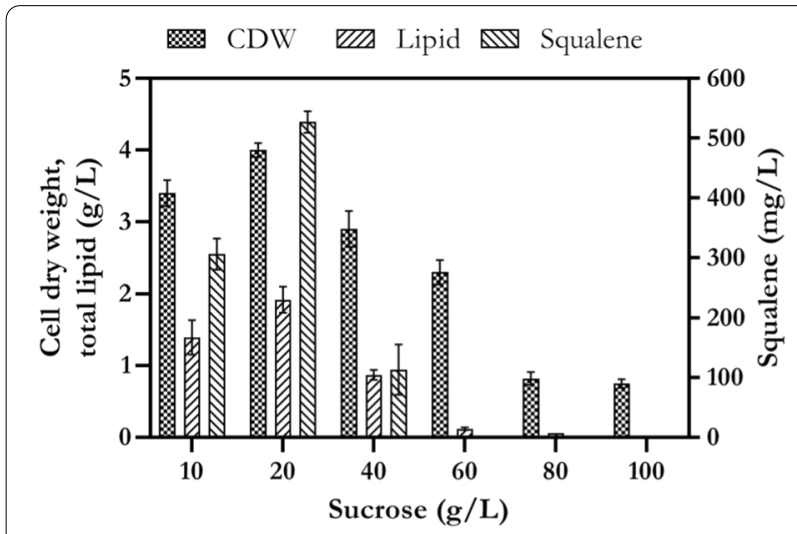

Fig. 7 The effect of different concentrations of sucrose on cell growth, lipid and squalene production by Rhodosporidium sp. DR37 at $30^{\circ} \mathrm{C}$ and $150 \mathrm{rpm}$ lipid production of Rhodosporidium sp. DR37 were decreasing while the concentration of sucrose was increasing more than $40 \mathrm{~g} / \mathrm{L}$ in the culture medium. Jiru et al. showed that optimum glucose concentration for maximum biomass and lipid production by Rhodosporidium kratochvilovae SY89 was 50 g/L [63]. Patel et al. showed that the content of polyunsaturated fatty acids such as linoleic acid was significantly higher in Rhodosporidium kratochvilovae HIMPA1 while cultivated on medium containing sucrose than medium containing glucose [64]. It could be concluded that sucrose was a favorable carbon source for production of fatty acids and compounds which have more than one double bond in their structure.

\section{The effect of temperature on cell growth, lipid and squalene production}

After determination of proper carbon and nitrogen sources and seawater concentration, temperature and $\mathrm{pH}$ were used to test their effects on cell growth, lipid and squalene production by Rhodosporidium sp. DR37. The effect of the temperature was tested from 15 to $37^{\circ} \mathrm{C}$. As shown in Fig. 8, an increase in cell growth, lipid and squalene production was observed when the temperature was increased from 15 to $25^{\circ} \mathrm{C}$ in culture medium. At $25{ }^{\circ} \mathrm{C}$, biomass, lipid and squalene were $4.9,2.85 \mathrm{~g} / \mathrm{L}$ and $614 \mathrm{mg} / \mathrm{L}$, respectively. Rhodosporidium sp. DR37 showed its maximum growth and squalene production at $25^{\circ} \mathrm{C}(p<0.05)$. Biomass and squalene were decreased to $4.2 \mathrm{~g} / \mathrm{L}$ and $501 \mathrm{mg} / \mathrm{L}$, when temperature was increased to $30{ }^{\circ} \mathrm{C}$. The minimum level of squalene $(33 \mathrm{mg} / \mathrm{L})$ was obtained at $37{ }^{\circ} \mathrm{C}$. Raising temperature to $37^{\circ} \mathrm{C}$ showed a statistically significant negative effect on cell growth and squalene production $(p<0.05)$. So, culture medium that was incubated at colder temperature showed best condition for growth and squalene production by

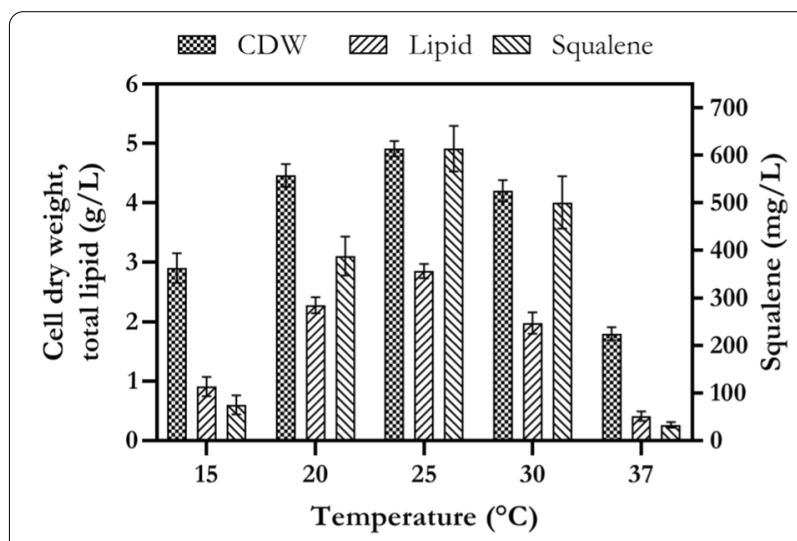

Fig. 8 The effect of different temperatures on cell growth, lipid and squalene production by Rhodosporidium sp. DR37 at $150 \mathrm{rpm}$ 
Rhodosporidium sp. DR37. Actually, a shift to a colder temperature probably can regulate biosynthesis pathways towards squalene and sterol production and accumulation [65]. Also, Wang et al. reported that an increase in temperature from 30 to $35^{\circ} \mathrm{C}$ significantly decreased biomass and lipid production by Rhodosporidium TJUWZ4 [26]. They reported that temperature range of $20-25{ }^{\circ} \mathrm{C}$ is favorable for lipid production by Rhodosporidium TJUWZ4. Temperature can regulate sterol biosynthesis pathway in yeasts and subsequently the sterol metabolite profile can change during yeast growth at low $\left(15-25^{\circ} \mathrm{C}\right)$ or high temperatures $\left(30-37^{\circ} \mathrm{C}\right)[65]$.

\section{The effect of initial medium $\mathrm{pH}$ on cell growth, lipid and squalene production}

As shown in Fig. 9, it was found that the initial medium pH 5 and 7 had similar effects on cell growth, lipid and squalene production. The amounts of biomass, lipid and squalene were $4.28,2.61 \mathrm{~g} / \mathrm{L}$ and $570 \mathrm{mg} / \mathrm{L}$ at $\mathrm{pH} 5$, and 4.88, $2.7 \mathrm{~g} / \mathrm{L}$ and $604 \mathrm{mg} / \mathrm{L}$ at $\mathrm{pH} 7$, respectively. But at initial medium $\mathrm{pH} 9$, a significant decrease $\left(p^{<} 0.05\right)$ in cell growth, lipid and squalene was observed to 2.59, $0.8 \mathrm{~g} / \mathrm{L}$ and $144 \mathrm{mg} / \mathrm{L}$, respectively. Rhodosporidium sp. DR37 showed good adaptation to initial medium $\mathrm{pH}$ 5 similar to $\mathrm{pH} 7$. Increasing of $\mathrm{pH}$ to 9 had a negative effect on cell growth and squalene production in comparison to $\mathrm{pH} 5$ and 7. These results are in accordance with Wang et al. [26]. Their results showed that two strains of Rhodosporidium TJUWZ4 and Rhodosporidium TJUWZA11 were able to accumulate lipid in media with initial $\mathrm{pH}$ range of 3-7. They concluded that this acid tolerance property makes both strains good candidates for high lipid production in media with initial low $\mathrm{pH}$. Therefore, the presence of initial low $\mathrm{pH}$ in culture medium is a good factor for prevention of microbial contaminations in fermentation broth.

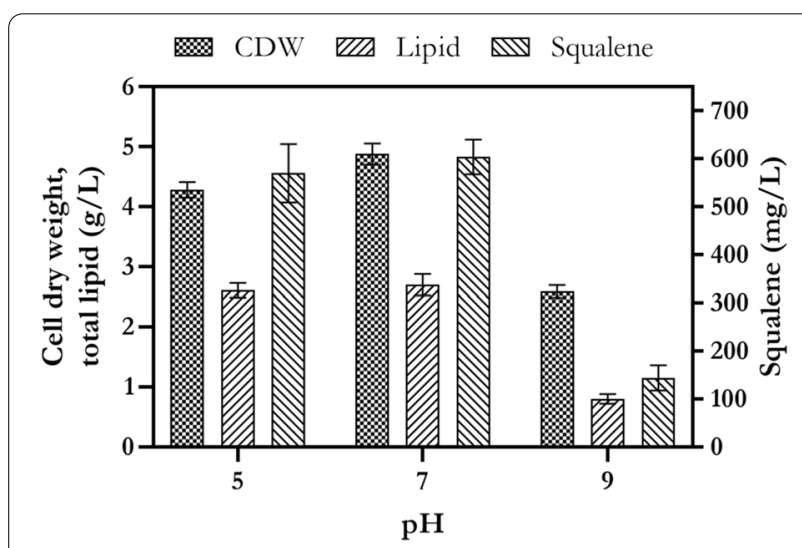

Fig. 9 The effect of various $\mathrm{pH}$ on cell growth, lipid and squalene production by Rhodosporidium sp. DR37 at $25^{\circ} \mathrm{C}$ and $150 \mathrm{rpm}$
Finally, the optimum culture condition was included $20 \mathrm{~g} / \mathrm{L}$ sucrose, $5 \mathrm{~g} / \mathrm{L}$ peptone, $20 \% \mathrm{v} / \mathrm{v}$ seawater and $\mathrm{pH} 7$ at $25{ }^{\circ} \mathrm{C}$. Cell growth, lipid and squalene production were monitored in optimized shake-flask culture condition during $120 \mathrm{~h}$. As shown in Fig. 10, the amount of squalene was increasing during $72 \mathrm{~h}$ of cultivation. The maximum amount of lipid $(2.86 \mathrm{~g} / \mathrm{L})$ and squalene $(619 \mathrm{mg} / \mathrm{L})$ was achieved at $72 \mathrm{~h}$ of incubation. Both lipid and squalene production were decreased after $72 \mathrm{~h}$ and reached to $1.8 \mathrm{~g} / \mathrm{L}$ and $181 \mathrm{mg} / \mathrm{L}$ at $120 \mathrm{~h}$, respectively.

As shown in Fig. 11, lipid content (\% of CDW) and squalene content (\% of total lipid) in Rhodosporidium sp. DR37 cultivated in optimized medium were investigated
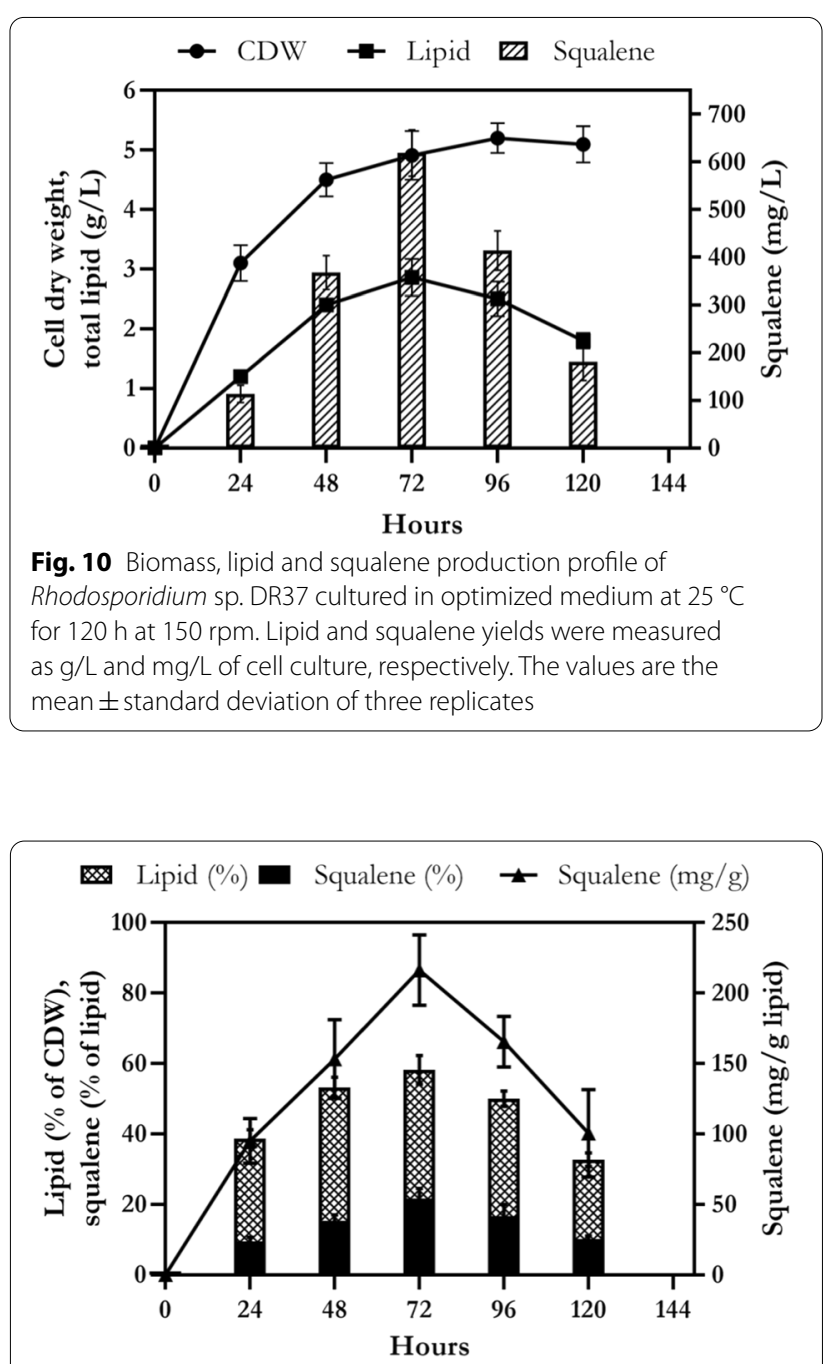

Fig. 11 Profile of lipid and squalene content of Rhodosporidium sp. DR37 cultured in optimized medium at $25^{\circ} \mathrm{C}$ for $120 \mathrm{~h}$ at $150 \mathrm{rpm}$. Lipid and squalene content were measured as \% of CDW and total lipid, respectively. Also squalene content mg/g CDW was determined. The values are the mean \pm standard deviation of three replicates 
by time course analysis. The lipid content was $38.7 \%$ and $53.3 \%$ at 24 and $48 \mathrm{~h}$, respectively, and reached to its maximum level (58.2\%) at $72 \mathrm{~h}$. A similar pattern was observed for squalene content. The maximum content of squalene (21.6\%) was achieved at $72 \mathrm{~h}$ and then decreased to $10.1 \%$ at $120 \mathrm{~h}$.

\section{Comparison of kinetic parameters in production and stationary phases of Rhodosporidium sp. DR37}

As shown in Fig. 10, profile of cell growth, lipid and squalene production in Rhodosporidium sp. DR37 can be divided into two phases. The first stage represents the production phase $(0-72 \mathrm{~h})$ and the second stage refers to the stationary or consumption phase (72$120 \mathrm{~h})$. Table 2 shows kinetic parameters of production phase $(0-72 \mathrm{~h})$ and stationary phase $(72-120 \mathrm{~h}$ ) of Rhodosporidium sp. DR37 in optimized medium. Kinetic parameters including $\mu_{\max }\left(\mathrm{h}^{-1}\right), q_{s}\left(\mathrm{~h}^{-1}\right), q_{p}$ $\left(\mathrm{h}^{-1}\right), q_{s q}\left(\mathrm{~h}^{-1}\right), Y_{x / s}(\%), Y_{p / s}(\%)$ and $Y_{s q / s}(\%)$ were calculated and compared during these two phases. At the production phase, the value of $\mu_{\text {max }}, q_{s}, q_{p}$ and $q_{s q}$ were obtained $0.092,0.226,0.036$ and 0.010 , respectively. Also, $Y_{x / s}, Y_{p / s}$ and $Y_{s q / s}$ were calculated as 28.1, 16.3 and 3.5, respectively. A sharp increase and maximum level of biomass, lipid and squalene was observed at the end of this phase. As shown in Table 2, the values of $Y_{x / s}, Y_{p / s}$ and $Y_{s q / s}$ in the stationary phase were decreased to $11.9,-66.3$ and -27.4 , respectively. The significant decrease and difference $(p<0.05)$ in $Y_{x / s}, Y_{p / s}$ and $Y_{s q / s}$ after $72 \mathrm{~h}$ demonstrate that stationary phase was not only favorable for lipid and squalene production, but also accelerated their consumption. On the other hand, biomass, lipid and squalene were produced

Table 2 Comparison of the kinetic parameters of Rhodosporidium sp. DR37 at production phase (0-72 h) and stationary phase (72-120 h) in optimized medium

\begin{tabular}{lll}
\hline Kinetic parameters & \multicolumn{2}{l}{ Optimized medium } \\
\cline { 2 - 3 } & $\begin{array}{l}\text { Production phase } \\
(0-72 \mathrm{~h})\end{array}$ & $\begin{array}{l}\text { Stationary } \\
\text { phase } \\
(72-120 \mathrm{~h})\end{array}$ \\
\hline$\mu_{\max }\left(\mathrm{h}^{-1}\right)$ & 0.092 & - \\
$q_{s}\left(\mathrm{~h}^{-1}\right)$ & 0.226 & - \\
$q_{p}\left(\mathrm{~h}^{-1}\right)$ & 0.036 & - \\
$q_{s q}\left(\mathrm{~h}^{-1}\right)$ & 0.010 & - \\
$Y_{x / s}(\%)$ & $28.1^{\mathrm{a}}$ & $11.9^{\mathrm{b}}$ \\
$Y_{p / s}(\%)$ & $16.3^{\mathrm{a}}$ & $-66.3^{\mathrm{b}}$ \\
$Y_{s q / s}(\%)$ & $3.5^{\mathrm{a}}$ & $-27.4^{\mathrm{b}}$ \\
\hline
\end{tabular}

Different letters $(a, b)$ in the same row show significant difference between the parameters $\left(p^{<} 0.05\right)$. $\mu_{\max }$ maximum specific cell growth rate, $q_{p}$ specific lipid accumulation rate, $q_{s q}$ specific squalene accumulation rate, $q_{s}$ specific sucrose consumption rate, $Y_{x / s}$ growth yield, $Y_{p / s}$ lipid yield, $Y_{s q / s}$ squalene yield in high amount during exponential growth phase. Therefore, it can be mentioned that production of lipid and squalene is growth-dependent in Rhodosporidium sp. DR37. The significant decline in the values of $Y_{x / s}$, $Y_{p / s}$ and $Y_{s q / s}$ in the stationary phase, demonstrated the high lipid and squalene consumption rate during this phase. As most of the carbon source was consumed after $72 \mathrm{~h}$ (data not shown), accumulation of lipid and squalene was stopped and the content of intracellular lipids decreased rapidly between 72 and $120 \mathrm{~h}$. It could be mentioned that lipid content can be used as a source of energy storage during starvation. Taking into account the cell starvation in stationary phase, acceleration of lipid and squalene consumption can provide more energy for cellular activities and maintenance. Guerreiro et al. [66] obtained $Y_{p / s}$ of $0.03 \mathrm{~g} / \mathrm{g}$ when Rhodosporidium toruloides CECT 1499 was cultivated in shake flask with lipid production medium containing $13 \mathrm{~g} / \mathrm{L}$ glucose and $0.75 \mathrm{~g} / \mathrm{L} \mathrm{YE}$ at $150 \mathrm{rpm}$ and $30{ }^{\circ} \mathrm{C}$ for $146 \mathrm{~h}$. Another research work on Rhodosporidium toruloides NCYC 921 has reported $Y_{p / s}$ of 0.08 and $0.13 \mathrm{~g} / \mathrm{g}$ in carbon or nitrogen-limiting batch medium in bioreactor, respectively [67]. These obtained yields were lower than obtained $Y_{p / s}$ by Rhodosporidium sp. DR37, indicating optimized medium supports the growth of Rhodosporidium sp. DR37 and subsequent accumulation of lipid and squalene during production phase.

It has been reported that two strains of Pseudozyma and three strains of Aurantiochytrium are able to produce significant amount of squalene (Table 3). The final yield of $1290 \mathrm{mg} / \mathrm{L}$ with content of $33.07 \%$ was achieved for production of squalene by Aurantiochytrium $18 \mathrm{~W}-3 \mathrm{a}$ [38]. Another research work on this strain has reported yield and maximum content of squalene as $900 \mathrm{mg} / \mathrm{L}$ and $68.99 \%$, respectively [17]. It has been reported that the highest content of squalene was achieved by Aurantiochytrium Yonez5-1 as $74.05 \%$ with yield of $1073.66 \mathrm{mg} / \mathrm{L}$ [13]. In this study, Rhodosporidium sp. DR37 showed squalene yield of $619 \mathrm{mg} / \mathrm{L}$ and content of $21.6 \%$. Also, two strains of Pseudozyma were reported to be able to produce $340-2445 \mathrm{mg} / \mathrm{L}$ of squalene.

The yield of the produced squalene by Rhodosporidium sp. DR37 was 1.8 times more than produced squalene by Pseudozyma sp. JCC 207 [16] and 3.9 times less than produced squalene by Pseudozyma sp. SD301. It must be considered that $2445 \mathrm{mg} / \mathrm{L}$ produced squalene by Pseudozyma sp. SD301 was achieved in fed-batch fermentation in a 5-L bioreactor [23], while $619 \mathrm{mg} / \mathrm{L}$ produced squalene by Rhodosporidium sp. DR37 was obtained in a shake-flask cultivation medium. 
Table 3 Comparison of the squalene yield and content by Rhodosporidium sp. DR37 mentioned in this study

\begin{tabular}{|c|c|c|c|c|}
\hline \multirow[t]{2}{*}{ Strain } & \multicolumn{4}{|l|}{ Shake-flask studies } \\
\hline & Squalene yield (mg/L) & Squalene content (\% of lipid) & Cultivation mode & References \\
\hline Aurantiochytrium $18 \mathrm{~W}-3 \mathrm{a}$ & 1290 & $33.07 \%$ & Shake flask & {$[38]$} \\
\hline Aurantiochytrium Yonez5-1 & 1073.66 & $74.05 \%$ & Shake flask & [13] \\
\hline Aurantiochytrium $18 \mathrm{~W}-3 \mathrm{a}$ & 900 & $68.99 \%$ & Shake flask & [17] \\
\hline Pseudozyma sp. JCC 207 & 340.52 & NR & Shake flask & [23] \\
\hline Pseudozyma sp. SD301 & 2445 & NR & Fed-batch fermentation & {$[16]$} \\
\hline Rhodosporidium sp. DR37 & 619 & $21.6 \%$ & Shake flask & This study \\
\hline
\end{tabular}

NR not reported

\section{Conclusion}

Lipid and carotenoids production has been widely studied in Rhodosporidium species. This oleaginous yeast strain is currently being used for production of lipids in large-scale bioreactors. However, in this study, we demonstrated that Rhodosporidium sp. DR37 is also a favorable and promising candidate for production of squalene. By cultivation of Rhodosporidium sp. DR37 in optimized medium, highest squalene accumulation $(619 \mathrm{mg} / \mathrm{L})$ and content (21.6\% of total lipid) were achieved. Moreover, Rhodosporidium sp. DR37 was able to produce significant amount of squalene in a wide range of seawater concentration $(0-50 \% \mathrm{v} / \mathrm{v})$, temperature $\left(20-30{ }^{\circ} \mathrm{C}\right)$ and $\mathrm{pH}(5-7)$. Although, the highest amount of squalene was achieved in optimized medium with $20 \% \mathrm{v} / \mathrm{v}$ seawater, $25^{\circ} \mathrm{C}$ and $\mathrm{pH} 7$. Comparison of $Y_{x / s}, Y_{p / s}$ and $Y_{s q / s}$ during growth of Rhodosporidium sp. DR37 in optimized medium revealed that lipid and squalene were accumulated in production phase and then consumed in stationary phase. Interestingly, cultivation and growth of Rhodosporidium sp. DR37 on medium containing sucrose as sole carbon source indicated that squalene can be co-produced with other high-value metabolites such as carotenoids from consumption of cost-effective and cheap feedstocks. Therefore, these results prove further investigations on squalene production in fed-batch fermentation in bioreactor which is the subject of our forthcoming research work.

\section{Acknowledgements}

The authors are grateful to the central laboratory of the Graduate University of Advanced Technology for GC and HPLC analysis. Also, the authors thank Batool Lashkari for FT-IR spectroscopy.

\section{Authors' contributions}

SS and MM designed the study and interpreted the results. SS and FK carried out the experimental works. Also, the manuscript was prepared by SS and MM. All authors read and approved the final manuscript.

\section{Funding}

This research has been supported by the Institute of Science and High Technology and Environmental Sciences, Graduate University of Advanced Technology (Kerman, Iran) under grant number of 7.S.98.233.

\section{Availability of data and materials}

All data generated or analyzed during this study are included in this published article.

\section{Declarations}

Ethics approval and consent to participate

Not applicable.

\section{Consent for publication}

Not applicable.

\section{Competing interests}

The authors declare that they have no competing interests.

Received: 20 January 2021 Accepted: 1 April 2021

Published online: 15 April 2021

\section{References}

1. Ghimire GP, Thuan NH, Koirala N, Sohng JK. Advances in biochemistry and microbial production of squalene and its derivatives. J Microbiol Biotechnol. 2016:26:441-51.

2. Micera M, Botto A, Geddo F, Antoniotti S, Bertea CM, Levi R, Gallo MP, Querio G. Squalene: more than a step toward sterols. Antioxidants (Basel). 2020;9:688.

3. Kim SK, Karadeniz F. Biological importance and applications of squalene and squalane. Adv Food Nutr Res. 2012;65:223-33.

4. Naziri E, Tsimidou MZ. Formulated squalene for food related applications. Recent Pat Food Nutr Agric. 2013;5:83-104.

5. Bhilwade HN, Tatewaki N, Nishida H, Konishi T. Squalene as novel food factor. Curr Pharm Biotechnol. 2010;11:875-80.

6. Tegenge MA, Von Tungeln LS, Mitkus RJ, Anderson SA, Vanlandingham MM, Forshee RA, Beland FA. Pharmacokinetics and biodistribution of squalene-containing emulsion adjuvant following intramuscular injection of H5N1 influenza vaccine in mice. Regul Toxicol Pharmacol. 2016;81:113-9.

7. Yoshida M, Tanabe $Y$, Yonezawa N, Watanabe M. Energy innovation potential of oleaginous microalgae. Biofuels. 2012;3:761-81.

8. Muller EE, Sheik AR, Wilmes P. Lipid-based biofuel production from wastewater. Curr Opin Biotechnol. 2014;30:9-16.

9. Gujjala LKS, Kumar SPJ, Talukdar B, Dash A, Kumar S, Sherpa KC, Banerjee R. Biodiesel from oleaginous microbes: opportunities and challenges. Biofuels. 2017;10:45-59.

10. Patel A, Karageorgou D, Rova E, Katapodis P, Rova U, Christakopoulos P, Matsakas L. An overview of potential oleaginous microorganisms and their role in biodiesel and omega-3 fatty acid-based industries. Microorganisms. 2020;8:434.

11. Gohil N, Bhattacharjee G, Khambhati K, Braddick D, Singh V. Engineering strategies in microorganisms for the enhanced production of squalene: advances, challenges and opportunities. Front Bioeng Biotechnol. 2019;7:50. 
12. Xu W, Ma X, Wang Y. Production of squalene by microbes: an update. World J Microbiol Biotechnol. 2016;32:195.

13. Nakazawa A, Kokubun Y, Matsuura H, Yonezawa N, Kose R, Yoshida M, Tanabe Y, Kusuda E, Thang DV, Ueda M, et al. TLC screening of thraustochytrid strains for squalene production. J Appl Phycol. 2014;26:29-41.

14. Liu H, Wang F, Deng L, Xu P. Genetic and bioprocess engineering to improve squalene production in Yarrowia lipolytica. Bioresour Technol. 2020;317:123991.

15. Spanova M, Daum G. Squalene - biochemistry, molecular biology, process biotechnology, and applications. Eur J Lipid Sci Technol. 2011;113:1299-320.

16. Song X, Wang X, Tan Y, Feng Y, Li W, Cui Q. High production of squalene using a newly isolated yeast-like strain Pseudozyma sp SD301. J Agric Food Chem. 2015;63:8445-51.

17. Nakazawa A, Matsuura H, Kose R, Kato S, Honda D, Inouye I, Kaya K, Watanabe MM. Optimization of culture conditions of the thraustochytrid Aurantiochytrium sp. strain 18W-13a for squalene production. Bioresour Technol. 2012;109:287-91.

18. Shakeri S, Amoozyan N, Fekrat F, Maleki M. Antigastric cancer bioactive Aurantiochytrium oil rich in docosahexaenoic acid: from media optimization to cancer cells cytotoxicity assessment. J Food Sci. 2017;82:2706-18.

19. Patel A, Liefeldt S, Rova U, Christakopoulos P, Matsakas L. Co-production of DHA and squalene by thraustochytrid from forest biomass. Sci Rep. 2020;10:1992.

20. Sameshima-Yamashita Y, Watanabe T, Tanaka T, Tsuboi S, Yarimizu T, Morita T, Koike H, Suzuki K, Kitamoto H. Construction of a Pseudozyma antarctica strain without foreign DNA sequences (self-cloning strain) for high yield production of a biodegradable plastic-degrading enzyme. Biosci Biotechnol Biochem. 2019:83:1547-56.

21. Takakuwa N, Nagahama S, Matsumura H, Kinoshita M, Ohnishi M. Efficient conversion of crude glycerol into triacylglycerol by the yeast Pseudozyma sp TYC-2187 for biodiesel production. J Oleo Sci. 2013;62:605-12.

22. Morita T, Takashima M, Fukuoka T, Konishi M, Imura T, Kitamoto D. Isolation of basidiomycetous yeast Pseudozyma tsukubaensis and production of glycolipid biosurfactant, a diastereomer type of mannosylerythritol lipid-B. Appl Microbiol Biotechnol. 2010;88:679-88.

23. Chang MH, Kim HJ, Jahng KY, Hong SC. The isolation and characterization of Pseudozyma sp JCC 207, a novel producer of squalene. Appl Microbiol Biotechnol. 2008;78:963-72.

24. Wen Z, Zhang S, Odoh CK, Jin M, Zhao ZK. Rhodosporidium toruloides-a potential red yeast chassis for lipids and beyond. FEMS Yeast Res. 2020. https://doi.org/10.1093/femsyr/foaa038.

25. Singh G, Sinha S, Bandyopadhyay KK, Lawrence M, Prasad R, Paul D. Triauxic growth of an oleaginous red yeast Rhodosporidium toruloides on waste "extract" for enhanced and concomitant lipid and beta-carotene production. Microb Cell Fact. 2018;17:1-10.

26. Wang Q, Cui Y, Sen B, Ma W, Zheng RL, Liu X, Wang G. Characterization and robust nature of newly isolated oleaginous marine yeast $R$ hodosporidium spp. from coastal water of Northern China. AMB Express. 2017;7:1-13.

27. Yaegashi J, Kirby J, Ito M, Sun J, Dutta T, Mirsiaghi M, Sundstrom ER, Rodriguez A, Baidoo E, Tanjore D, et al. Rhodosporidium toruloides: a new platform organism for conversion of lignocellulose into terpene biofuels and bioproducts. Biotechnol Biofuels. 2017;10:1-13.

28. Zhu Z, Zhang S, Liu H, Shen H, Lin X, Yang F, Zhou YJ, Jin G, Ye M, Zou H, et al. A multi-omic map of the lipid-producing yeast Rhodosporidium toruloides. Nat Commun. 2012;3:1-12.

29. Xu J, Liu D. Exploitation of genus Rhodosporidium for microbial lipid production. World J Microbiol Biotechnol. 2017;33:54.

30. Soccol CR, Dalmas Neto CJ, Soccol VT, Sydney EB, da Costa ESF, Medeiros $A B P$, Vandenberghe LPS. Pilot scale biodiesel production from microbial oil of Rhodosporidium toruloides DEBB 5533 using sugarcane juice: performance in diesel engine and preliminary economic study. Bioresour Technol. 2017:223:259-68.

31. Park YK, Nicaud JM, Ledesma-Amaro R. The engineering potential of Rhodosporidium toruloides as a workhorse for biotechnological applications. Trends Biotechnol. 2018;36:304-17.

32. Qi F, Shen P, Hu R, Xue T, Jiang X, Qin L, Chen Y, Huang J. Carotenoids and lipid production from Rhodosporidium toruloides cultured in tea waste hydrolysate. Biotechnol Biofuels. 2020;13:1-12.
33. Saini R, Hegde K, Osorio-Gonzalez CS, Brar SK, Vezina P. Evaluating the potential of Rhodosporidium toruloides-1588 for high lipid production using undetoxified wood hydrolysate as a carbon source. Energies. 2020;13:5960

34. Kitahara Y, Yin T, Zhao X, Wachi M, Du W, Liu D. Isolation of oleaginous yeast (Rhodosporidium toruloides) mutants tolerant of sugarcane bagasse hydrolysate. Biosci Biotechnol Biochem. 2014;78:336-42.

35. Fujita SI, Senda Y, Nakaguchi S, Hashimoto T. Multiplex PCR using internal transcribed spacer 1 and 2 regions for rapid detection and identification of yeast strains. J Clin Microbiol. 2001;39:3617-22.

36. Tamura K, Dudley J, Nei M, Kumar S. MEGA4: Molecular evolutionary genetics analysis (MEGA) software version 4.0. Mol Biol Evol. 2007;24:1596-9.

37. Iverson SJ, Lang SL, Cooper MH. Comparison of the Bligh and Dyer and Folch methods for total lipid determination in a broad range of marine tissue. Lipids. 2001;36:1283-7.

38. Kaya K, Nakazawa A, Matsuura H, Honda D, Inouye I, Watanabe MM Thraustochytrid Aurantiochytrium sp. 18W-13a accummulates high amounts of squalene. Biosci Biotechnol Biochem. 2011;75:2246-8.

39. Burja AM, Armenta RE, Radianingtyas H, Barrow CJ. Evaluation of fatty acid extraction methods for Thraustochytrium sp. ONC-T18. J agri food chem. 2007:55:4795-801.

40. Matsuura H, Watanabe MM, Kaya K. Squalene quantification using octadecylbenzene as the internal standard. Procedia Environ Sci. 2012;15:43-6.

41. Ji XJ, Huang H, Du J, Zhu JG, Ren LJ, Hu N, Li S. Enhanced 2,3-butanedio production by Klebsiella oxytoca using a two-stage agitation speed control strategy. Bioresour Technol. 2009;100:3410-4

42. Ren $L$, Ji XJ, Huang H, Qu L, Feng Y, Tong QQ, Ouyang PK. Development of a stepwise aeration control strategy for efficient docosahexaenoic acid production by Schizochytrium sp. Appl Microbiol Biotechnol. 2010;87:1649-56

43. Aime MC, Toome M, McLaughlin DJ. Pucciniomycotina. In: McLaughlin DJ, Spatafora JW, editors. The Mycota, systematics and evolution Part A. Berlin: Springer-Verlag; 2014.

44. Boekhout T, Fonseca Á, Sampaio J, Bandoni R, Fell J, Kwon-Chung K. Discussion of teleomorphic and anamorphic basidiomycetous yeasts. In: The yeasts: a taxonomic study. London, UK: Elsevier; 2011;1339-1372. https:// doi.org/10.1016/B978-0-444-52149-1.00100-2

45. Wang QM, Yurkov AM, Goker M, Lumbsch HT, Leavitt SD, Groenewald M, Theelen B, Liu XZ, Boekhout T, Bai FY. Phylogenetic classification of yeasts and related taxa within Pucciniomycotina. Stud Mycol. 2015;81:149-89.

46. Lyman M, Urbin S, Strout C, Rubinfeld B. The oleaginous red yeast Rhodotorula/Rhodosporidium: a factory for industrial bioproducts. In: Yeasts in biotechnology. IntechOpen; 2019. https://doi.org/10.5772/intec hopen.84129

47. Zhou W, Wang W, Li Y, Zhang Y. Lipid production by Rhodosporidium toruloides $Y 2$ in bioethanol wastewater and evaluation of biomass energetic yield. Bioresour Technol. 2013;127:435-40.

48. Xu J, Zhao X, Wang W, Du W, Liu D. Microbial conversion of biodiesel byproduct glycerol to triacylglycerols by oleaginous yeast Rhodosporidium toruloides and the individual effect of some impurities on lipid production. Biochem Eng J. 2012;65:30-6.

49. Munch $G$, Sestric R, Sparling R, Levin DB, Cicek N. Lipid production in the under-characterized oleaginous yeasts, Rhodosporidium babjevae and Rhodosporidium diobovatum, from biodiesel-derived waste glycerol. Bioresour Technol. 2015;185:49-55.

50. Wang Q, Guo FJ, Rong YJ, Chi ZM. Lipid production from hydrolysate of cassava starch by Rhodosporidium toruloides 21167 for biodiesel making Renew Energy. 2012;46:164-8.

51. Milla P, Athenstaedt K, Viola F, Oliaro-Bosso S, Kohlwein SD, Daum G, Balliano G. Yeast oxidosqualene cyclase (Erg7p) is a major component of lipid particles. J Biol Chem. 2002;277:2406-12.

52. Patel A, Rova U, Christakopoulos P, Matsakas L. Simultaneous production of DHA and squalene from Aurantiochytrium sp. grown on forest biomass hydrolysates. Biotechnol Biofuels. 2019;12:1-12.

53. Hull CM, Loveridge EJ, Rolley NJ, Donnison IS, Kelly SL, Kelly DE. Co-production of ethanol and squalene using a Saccharomyces cerevisiae ERG1 (squalene epoxidase) mutant and agro-industrial feedstock. Biotechnol Biofuels. 2014;7:1-9. 
54. Otagiri M, Khalid A, Moriya S, Osada H, Takahashi S. Novel squaleneproducing thraustochytrids found in mangrove water. Biosci Biotechnol Biochem. 2017;81:2034-7.

55. Hall DW, Marshall SN, Gordon KC, Killeen DP. Rapid quantitative determination of squalene in shark liver oils by Raman and IR spectroscopy. Lipids. 2016;51:139-47.

56. Naspolini BF, Machado ACO, Cravo Junior WB, Freire DMG, Cammarota MC. Bioconversion of sugarcane vinasse into high-added value products and energy. Biomed Res Int. 2017;2017:8986165.

57. Wiebe MG, Koivuranta K, Penttila M, Ruohonen L. Lipid production in batch and fed-batch cultures of Rhodosporidium toruloides from 5 and 6 carbon carbohydrates. BMC Biotechnol. 2012;12:1-10.

58. Gray VL, Muller CT, Watkins ID, Lloyd D. Peptones from diverse sources: pivotal determinants of bacterial growth dynamics. J Appl Microbiol. 2008;104:554-65.

59. Germec M, Turhan I. Enhanced production of Aspergillus niger inulinase from sugar beet molasses and its kinetic modeling. Biotechnol Lett. 2020;42:1939-55

60. Germec M, Gurler HN, Ozcan A, Erkan SB, Karahalil E, Turhan I. Medium optimization and kinetic modeling for the production of Aspergillus niger inulinase. Bioprocess Biosyst Eng. 2020;43:217-32.

61. Wu S, Hu C, Jin G, Zhao X, Zhao ZK. Phosphate-limitation mediated lipid production by Rhodosporidium toruloides. Bioresour Technol. 2010;101:6124-9.

62. Tchakouteu SS, Kopsahelis N, Chatzifragkou A, Kalantzi O, Stoforos NG Koutinas AA, Aggelis G, Papanikolaou S. Rhodosporidium toruloides cultivated in $\mathrm{NaCl}$-enriched glucose-based media: adaptation dynamics and lipid production. Eng Life Sci. 2017;17:237-48.

63. Jiru TM, Groenewald M, Pohl C, Steyn L, Kiggundu N, Abate D. Optimization of cultivation conditions for biotechnological production of lipid by Rhodotorula kratochvilovae (syn, Rhodosporidium kratochvilovae) SY89 for biodiesel preparation. 3 Biotech. 2017;7:1-11.

64. Patel A, Pruthi V, Singh RP, Pruthi PA. Synergistic effect of fermentable and non-fermentable carbon sources enhances TAG accumulation in oleaginous yeast Rhodosporidium kratochvilovae HIMPA1. Bioresour Technol. 2015;188:136-44.

65. Loertscher J, Larson LL, Matson CK, Parrish ML, Felthauser A, Sturm A, Tachibana C, Bard M, Wright R. Endoplasmic reticulum-associated degradation is required for cold adaptation and regulation of sterol biosynthesis in the yeast Saccharomyces cerevisiae. Eukaryot Cell. 2006;5:712-22.

66. Guerreiro F, Constantino A, Lima-Costa E, Raposo S. A new combined approach to improved lipid production using a strictly aerobic and oleaginous yeast. Eng Life Sci. 2019;19:47-56.

67. Andrade R, Leal R, Roseiro J, Reis A, da Silva TL. Monitoring Rhodosporidium toruloides NCYC 921 batch fermentations growing under carbon and nitrogen limitation by flow cytometry. World J Microbiol Biotechnol. 2012;28:1175-84

\section{Publisher's Note}

Springer Nature remains neutral with regard to jurisdictional claims in published maps and institutional affiliations.
Ready to submit your research? Choose BMC and benefit from:

- fast, convenient online submission

- thorough peer review by experienced researchers in your field

- rapid publication on acceptance

- support for research data, including large and complex data types

- gold Open Access which fosters wider collaboration and increased citations

- maximum visibility for your research: over $100 \mathrm{M}$ website views per year

At BMC, research is always in progress.

Learn more biomedcentral.com/submissions 